\title{
Influence of Planting Dates on the Population Density of the Main Insect Pests on Onion Crop in Kafr El-Shekh Region. \\ Awadalla, S. S ${ }^{1}$; A. A. Taman ${ }^{2}$ and A. A. Aboria ${ }^{2}$ \\ 1 Economic Entomology Department, Faculty of Agriculture, Mansoura University, Mansoura, Egypt \\ ${ }^{2}$ Field crop Insect Pest Department, Plant Protection Research Institute, Agricultural Research Center, Sakha, Egypt
}

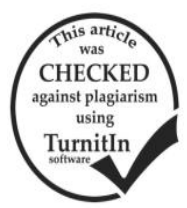

\section{ABSTRACT}

The current experiments were carried out at the Research Farm belonging to the Agricultural Research Station in Sakha, Kafr El Sheikh Governorate, where onion seedlings were planted on three different agricultural dates (December, January and February) during the 2013/14 and 2014/15 study seasons to study the effect of different planting dates on the population density of the main insect pests attacking onion crop. The onion thrips Thrips tabaci Lind showed the highest number and percentage in the third planting date during the first and second season which represented by 7605 individuals (52.57\%) and 7950 individuals (59.41\%), respectively. The highest number and percentage of the onion aphid, Aphis gossypii Glov, the cotton leaf hopper, Empoasca Lybica de Berg and the cotton whitefly Bemisia tabaci Genn the third planting date attractive during the two successive seasons. While, the onion Maggot Delia. Alliria Fonseca showed the highest number and percentage during the first and second planting dates during the first and second season, respectively. There were significant differences between planting dates in numbers of T. tabaci, A. gossypii, and E. lybica, whereas differences in numbers of $D$. alliria among planting dates were insignificant during the two study seasons.

Keywords: Aphis gossypii, Thrips tabaci, Dalia alliria, Empoasca lybica, attractive.

\section{INTRODUCTION}

In Egypt, Onion (Allium Cepa L.) is an important crop for both local consumption and exportation. According to statistics of Ministry of Agriculture and Land Reclamation, the total area cultivated with onion crop in 2006 exceeded 80 thousand feddans with an averaged production of 950 thousand tons of onion bulbs (Mahmoud, 2008). Onion plantations as well as bulbs during the storage are often subject to infestation with several insect species, resulting in decreasing of the crop quality and quantity. Onion plants are usually subject to infestation by different insect pests during their development stages like thrips Thrips tabaci Lind., the onion aphid Aphis gossypii Glov., the cotton leaf hopper Empoasca Lybica de Berg., the cotton white fly Bemisia tabaci Genn., and the serpentine leaf miner Liriomyza trifolii Burgess. Which caused yield losses (El-Sherif, 1971; Szwejda, 2005; Mahomoud, 2008 and Mahaffey; Cranszhaw, 2010; Ibrahim, 2010 and Blatt, 2015).

The population density of the main insect pests infesting Onion Crop was affected significantly by transplantation dates, where the insect pests affecting significantly positively or negatively by temperature degrees and the relative humidity (Hamdy and Salem, 1994; El-Khayat et al.,1997; Salman and AboElhagag,2001 and Hermize,2015).Therefore the present study was carried out during the two successive seasons 2013/14 and 2014/15 in kafr-el shekh region to evaluate the effect planting dates on the main insect pests infesting Onion Crop.

\section{MATERIALS AND METHODS}

The current experiments were carried out at the Research Farm belonging to the Agricultural Research Station in Sakha, Kafr El- Sheikh Governorate, where onion seedlings were planted on three different agricultural dates on December, January and February (during the 2013/14 and 2014/15 seasons) this was conducted to study the effect of different planting dates on the main insect pests attacking onion crop, plants were transplanting in three consecutive times 30 days intervals, i. e. the First planting date (Beginning of December), Second planting date (Beginning of January) and Third planting date (Beginning of February) for the Two successive seasons 2013/14 and 2014/15 at Kafr El-shekh Governorate. The experiments were applied on Variety Giza 20 and experimental area about $600 \mathrm{~m}^{2}$. (each planting date was about $200 \mathrm{~m}^{2}$ ) divided into four replicates, each replicate was $50 \mathrm{~m}^{2}$. Replicates arranged in Completely Randomized Design, each plot consisted of 5 rows wide and $10 \mathrm{~m}$ long with $10 \mathrm{~cm}$ within rows and five $\mathrm{cm}$ between plants. No pesticides were applied in the plots during the experiment throughout the two seasons. Normal agricultures practices were followed as recommended. Samples started one week after plantations. Ten plants were randomly selected from each plot, cutting at the morning from base, placed in plastic bags, and transferred to the laboratory for investigations. These samples were collected weekly from the second week of plantation till the time of harvest Hussain (1998).

The data obtained were analyzed using One-way ANOVA, and the Means were compared using Duncan's Multiple.

\section{RESULTS AND DISCUSSION}

Data presented in Table (1) recorded the total number and percentage of the main insect pests infesting onion crop in the different planting dates during the first season 2013/14 in Kafr EL-Shekh region. It can be noticed that, the highest total number and percentage of the main insect pests during the first season 2013/14 recorded in the third planting date and represented of 7605 indiv. (52.57\%) for T.tabaci, 3751 indiv. (25.93\%) for A.gossypii and 1256 indiv. (8.68\%) for E.lybica.On the other hand, the first planting date come in the second category and represented by 6616 indiv. (56.41\%) for T.tabaci, 2416 indiv. (20.60\%) for A.gossypii and 1142 indiv.(9.74\%) for E.lybica. Meanwhile, the first planting date recorded the highest total number and percentage for D.alliria followed by the second planting date and third planting date and 
represented by $467(3.94 \%), \quad 412(3.92 \%)$ and 324 indiv.(2.24\%), respectively.

Date represented in Table (2) showed the total number and percentage of the main insect pests infesting onion crop in the different planting dates the second season 2014/15 in Kafr El- Shekh region. It can be noticed that, the highest total number and percentage of the main insect pests during the second season 2014/15 recorded in the third planting date and represented of 7950 indiv. (59.41\%)for T.tabaci, 3055 indiv. (22.69\%)for A.gossypii and 1102 indiv. (8.18\%) for E.lybica.On the other hand, the first planting date come in the second category and represented by 6829 indiv. (58.41\%) for T.tabaci, 2610 iniv. (22.32\%) for A.gossypii and 910 indiv.(7.78\%) for E.lybica. Meanwhile, the first planting date recorded the highest total number and percentage for D.alliria followed by the second planting date and third planting date and represented by $489(4.18 \%), 410(3.94 \%)$ and 350 indiv. $(2.23 \%)$, respectively.

As a conclusion, data presented in Tables (1 and 2) indicated that T.tabaci recorded the highest total number and percentage in the third planting date during the two seasons $2013 / 14$ and $2014 / 15$ and represented by 7605 indiv. (52.57\%) and 7950 indiv. (59.41\%), respectively. Also, the highest total number and percentage for $A$. gossypii, E. Lybica $\mathrm{w}$ and B. tabaci were recorded in the third planting date during the two successive seasons. While, D. alliria recorded the highest total number and percentage during the First planting date followed by the Second planting date during the two seasons

Table 1. Total number and percentage of the main insect pests attacking Onion crop during season 2013/14.

\begin{tabular}{lcccccc}
\hline \multirow{2}{*}{$\begin{array}{l}\text { Insect } \\
\text { pests }\end{array}$} & \multicolumn{2}{c}{$\begin{array}{c}\text { First } \\
\text { planting date } \\
\text { No. }\end{array}$} & \multicolumn{2}{c}{$\begin{array}{c}\text { Second } \\
\text { planting date } \\
\text { No. }\end{array}$} & \multicolumn{2}{c}{$\begin{array}{c}\text { Third } \\
\text { planting date } \\
\text { No. }\end{array}$} \\
\hline T. tabaci. & 6616 & 56.41 & 5971 & 56.88 & 7605 & 52.57 \\
A. gossypii & 2416 & 20.60 & 2262 & 21.55 & 3751 & 25.93 \\
E. lybica & 1142 & 9.74 & 872 & 8.31 & 1256 & 8.68 \\
B. tabaci. & 494 & 4.21 & 424 & 4.03 & 598 & 4.13 \\
D. alliria & 467 & 3.94 & 412 & 3.92 & 324 & 2.24 \\
L. trifolii & 594 & 5.10 & 557 & 5.31 & 931 & 6.45 \\
Total & 11729 & 100 & 10498 & 100 & 14465 & 100 \\
\hline
\end{tabular}

Table 2. Total number and percentage of main insect pest attacking Onion crop during season 2014/15.

\begin{tabular}{lcccccc}
\hline \multirow{2}{*}{$\begin{array}{l}\text { Insect } \\
\text { pests }\end{array}$} & \multicolumn{2}{c}{$\begin{array}{c}\text { First } \\
\text { planting date } \\
\text { No. }\end{array}$} & \multicolumn{2}{c}{$\begin{array}{c}\text { Second } \\
\text { planting date } \\
\text { No. }\end{array}$} & \multicolumn{2}{c}{$\begin{array}{c}\text { Third } \\
\text { planting date } \\
\text { No. }\end{array}$} \\
\hline T. tabaci. & 6829 & 58.41 & 5997 & 58.98 & 7950 & 59.41 \\
A. gossypii & 2610 & 22.32 & 2253 & 22.15 & 3055 & 22.69 \\
E. lybica & 910 & 7.78 & 904 & 8.89 & 1102 & 8.18 \\
B. tabaci. & 294 & 2.52 & 256 & 2.52 & 373 & 2.77 \\
D. alliria & 489 & 4.18 & 410 & 3.94 & 350 & 2.23 \\
L. trifolii & 560 & 4.79 & 356 & 3.5 & 635 & 4.72 \\
Total & 11692 & 100 & 10167 & 100 & 13465 & 100 \\
\hline
\end{tabular}

As shown in Table (3) the results indicated to the average number of the main insect pests infesting Onion crop in the three planting dates during the first season2013/14 in Kafr EL-Shekh region. The third planting date recorded the highest average number of T.tabaci followed by the first planting date and the second planting date and represented by $412.6 \pm 50.9$, $390.7 \pm 45.3$ and $343.4 \pm 38.8$ indiv., respectively. Also, the third planting dates ranked the first category and attractive the highest average number of A.gossypii, and E.lybica followed by the first planting date and the second planting date with highly significant difference. On the other hand, the first planting date come in the first category and attractive the highest average number of D.alleria followed by the second planting and third planting date with insignificantly difference.

Data arranged in Table (4) the results indicated to the average number of the main insect pests infesting Onion crop in the three planting dates during the second season2014/15 in Kafr EL-Shekh region. The third planting date recorded the highest average number of T.tabaci followed by the first planting date and the second planting date and represented by $399.1 \pm 42.7$, $386.5 \pm 38.7$ and $323.8 \pm 29.2$ indiv., respectively. Also, the third planting dates ranked the first category and attractive the highest average number of A.gossypii, and E.lybica followed by the first planting date and the second planting date with highly significant difference. On the other hand, the first planting date come in the first category and attractive the highest average number of D.alleria followed by the second planting and third planting date with insignificantly difference.

As a conclusion, data represented in Tables (3 and 4) revealed that, The third planting date recorded the highest average number of T.tabaci, A.gossypii and E.lybica during the two successive season 2013/14 and 2014/15 with highly significant difference and represented by $(412.6 \pm 50.9$ and $399.1 \pm 42.7),(209.9 \pm 21.5$ and $159.1 \pm 23.2)$, and $(71.2 \pm$ 8.3 and $57.4 \pm 7.8$ ), respectively. Meanwhile, D.alliria recorded the highest average number in the first planting date during the two seasons $(29.1 \pm 6.9$ and $30.2 \pm 10.1)$ followed by the second planting date with insignificantly difference (24.2 \pm 6.7 and $25.6 \pm 8.7$ ), respectively.

Table 3. Average number of the main insect pests in the different planting dates during the first season 2013/14 in Kafr El-shekh region.

\begin{tabular}{lccc}
\hline $\begin{array}{l}\text { Insect } \\
\text { pests }\end{array}$ & $\begin{array}{c}\text { First } \\
\text { planting date }\end{array}$ & $\begin{array}{c}\text { Second } \\
\text { planting date }\end{array}$ & $\begin{array}{c}\text { Third } \\
\text { planting date }\end{array}$ \\
\hline T. tabaci. & $390.7 \mathrm{~b} \pm 45.3 \mathrm{~b}$ & $343.4 \pm 38.8 \mathrm{c}$ & $412.6 \pm 50.9 \mathrm{a}$ \\
A. gossypii & $147.6 \pm 27.1 \mathrm{~b}$ & $135.1 \pm 13.5 \mathrm{~b}$ & $209.9 \pm 21.5 \mathrm{a}$ \\
E. lybica & $67.9 \pm 5.7 \mathrm{~b}$ & $51.7 \pm 5.9 \mathrm{~b}$ & $71.2 \pm 8.3 \mathrm{a}$ \\
B. tabaci. & $29.6 \pm 2.8 \mathrm{a}$ & $26.1 \pm 3.2 \mathrm{a}$ & $32.7 \pm 4.4 \mathrm{a}$ \\
L. trifolii & $34.4 \pm 3.8 \mathrm{~b}$ & $30.7 \pm 3.9 \mathrm{~b}$ & $53.2 \pm 8.3 \mathrm{a}$ \\
D. alliria & $29.1 \pm 6.9 \mathrm{a}$ & $24.2 \pm 6.7 \mathrm{a}$ & $20.2 \pm 3.6 \mathrm{a}$ \\
\hline
\end{tabular}

In a row means followed by the same letter are not significantly different at the $5 \%$ level.

Table 4. Average number of main insect pests in the different planting dates during the Second season 2014/15 in Kafr El-shekh region.

\begin{tabular}{lccc}
\hline Insect & $\begin{array}{c}\text { First } \\
\text { pests }\end{array}$ & $\begin{array}{c}\text { Second } \\
\text { planting date }\end{array}$ & $\begin{array}{c}\text { Third } \\
\text { planting date }\end{array}$ \\
T. tabaci. & $386.5 \pm 38.7$ a & $323.8 \pm 29.2 \mathrm{~b}$ & $399.1 \pm 42.7 \mathrm{a}$ \\
A. gossypii & $153.9 \pm 20.7 \mathrm{ab}$ & $136.6 \pm 17.6 \mathrm{~b}$ & $159.1 \pm 23.2 \mathrm{a}$ \\
E. lybica & $55.8 \pm 6.7 \mathrm{a}$ & $51.6 \pm 6.5 \mathrm{a}$ & $57.4 \pm 7.8 \mathrm{a}$ \\
B. tabaci. & $16.8 \pm 2.4 \mathrm{a}$ & $15.2 \pm 2.4 \mathrm{a}$ & $20.9 \pm 3.5 \mathrm{a}$ \\
L. trifolii & $30.6 \pm 4.2 \mathrm{a}$ & $20.4 \pm 3.5 \mathrm{~b}$ & $33.8 \pm 5.1 \mathrm{a}$ \\
D. alliria & $30.2 \pm 10.1 \mathrm{a}$ & $25.6 \pm 8.7 \mathrm{a}$ & $21.8 \pm 6.4 \mathrm{a}$ \\
\hline
\end{tabular}

In a row means followed by the same letter are not significantly different at the $5 \%$ level. 
These results are in agreement with those of ElKhayat et al. (1997) who showed significant deference between three planting dates in the numbers of the main insect pests attacking Onion crops in Egypt.Thrips infestation increased with delay in sowing in both nursery ( $5^{\text {th }}$ of December) and field $\left(12^{\text {th }}\right.$ of January) conditions. Reddy and Gowdar (2006) found that the infestation incidence of thrips increased with delay in sowing from $5^{\text {th }}$ of June to $5^{\text {th }}$ of July and decreased from $15^{\text {th }}$ of July to $5^{\text {th }}$ of August. An increase in the thrips infestation incidence from $15^{\text {th }}$ of August to $5^{\text {th }}$ of September, accompanied by decrease in bulb yield. Soro et al. (2011) in Burkina Faso, recorded that the larvae of Helicoverpa armigera is the main pest on onion. They found thatthe number of $H$. armigera larvae increased during September compared to December plantations. Hermize (2015) recorded that lowest infestation of onion maggot $D$. alliria in the lower plant densities and first date of cultivation at both nursery and field level. Higher yield was obtained from the plants cultivated inthe first date of sowing.

\section{REFERENCES}

Blatt, S.; A. Ryan; S. Adams and J. Driscoll (2015). Onion Thrips tabaci (Thysanoptera: Thripidae)) in cabbage on Prince Edward Island: observations on planting date and variety choice. Springer Plus; 4:430.

Cohort Software (2004). Costat. www.cohort .com montery, California,USA.

El-Khyat, E. F.; F. F. Shalaby; F.M. Lotfy; A.R. Ibrahim (1997). Thrips infestation to onion plants in relation to onion variety, planting date and nitrogen fertilization. Annals of Agric. Sci. moshtohor; 35(3):1761-1777.

El-Sherif, A.R.A. (1971). Studies on insects infesting onion and garlic in field and storage. $\mathrm{Ph}, \mathrm{D}$, Thesis, Fac. Agric.,Cairo.Univ..Egypt 29pp.

Hamdy, M. k. and M. salem (1994). The effect of plantation dates of onion temperature and relative humidity on the population density of the onion thrips Thrips tabaci Lind. in Egypt. Annals Agric. Sci., Ain Shams Unive., Cairo ,39[1]: 417-424.
Hermize, F. B. (2015). Effect of sowing dates and planting density on the infestation of onion maggot (Delia alliaria Fonseca) in onion (Allium cepa L.) crops. J. Expe. Biolo. and Agric. Sci.; 3(2):202-206.

Hussain,A.,(1998).integrated pest management of onion thrips , Thrips tabai (Thysanoptra:Thripidae) in onion crop in Balochistan. Final Report, 1995-97, Agric. Res. Inst., Quetta, Pakistan pp:52.

Ibrahim, N. D. and A. A. Adesiyun (2010). Effect of rainfall in the control of onion thrips, Thrips tabaci Lindeman (Thysanoptera: Thripidae) in Sokoto, Nigeria.Agriculture and Biology J. North America;1(3):377-386.

Mahaffey, L. A. and W. S. Cranshaw, (2010). Thrips species associated with in Colorado. Southwestern Entomol. 35:1,45-50.

Mahmoud, H. H. (2008). Ecological Studies on certain insect pests of onion with special emphasis on the onion bulb fly Eumerus anoenus Loew. Ph.D. Thesis, Fac., Agric.,Cairo Unvi, Egypt.

Reddy, N.; Gowdar, S. B. (2006). Studies on effect of staggered sowing on incidence thrips, Thrips tabaci and bulb yield of onion. Advances in plant sci.; 19 (1): 139-142.

Salman, A. M. A; and G. H. Abou- Elhagag, (2001). Effect of sowing dates of faba bean on Thirps tabaci Lind. Population in Upper Egypt. Assiut Agric. Sci. 32:4.39-47.

Soro, S.; M. Doumbia; L. N. Yeboue; D. Dao and Y. Tano (2011). Influence of onion planting date on Helicoverpa armigera (Hubner) larvae population in Northern Burkina Faso. J. Appli. Biosci.; 46:3113-3119.

Szwejda, J. (2005). Pests threatening onion in Poland. Nowosci- Warzwniczy, 40:53-59.

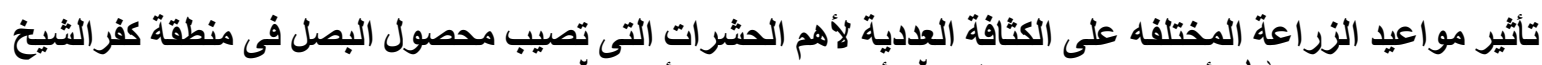

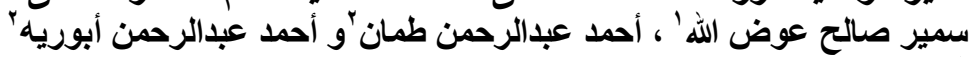





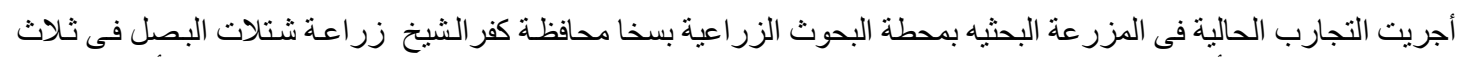

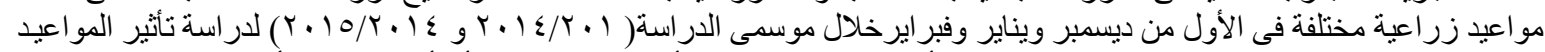

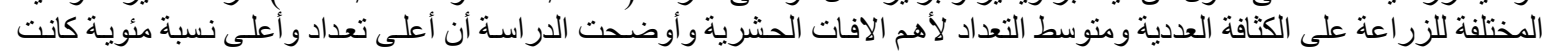

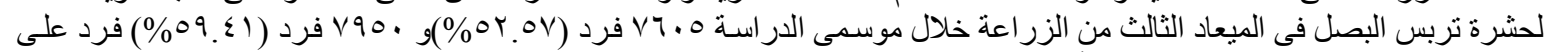

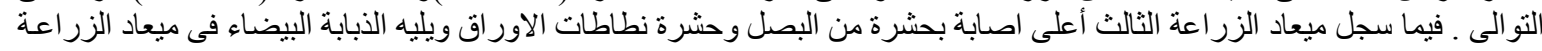





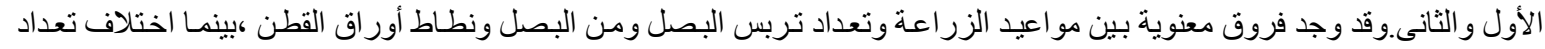

$$
\begin{aligned}
& \text { ذبابة البصل الصغيرة في مو اعيد الزر اعة كانت غير معند معنوية. }
\end{aligned}
$$

